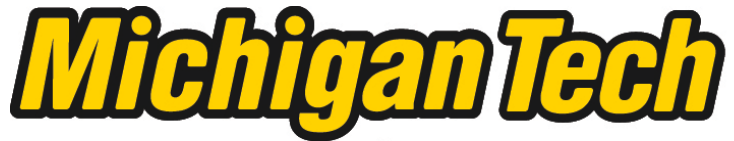 \\ Michigan Technological University Create the Future Digital Commons @ Michigan Tech
}

Dissertations, Master's Theses and Master's Reports - Open

Dissertations, Master's Theses and Master's

Reports

2013

\section{Assessment of Seismic Damage of Buildings and Related Environmental Impacts}

Carley A. Feese

Michigan Technological University

Follow this and additional works at: https://digitalcommons.mtu.edu/etds

Part of the Civil Engineering Commons, and the Environmental Engineering Commons Copyright 2013 Carley A. Feese

\section{Recommended Citation}

Feese, Carley A., "Assessment of Seismic Damage of Buildings and Related Environmental Impacts", Master's Thesis, Michigan Technological University, 2013.

https://doi.org/10.37099/mtu.dc.etds/456

Follow this and additional works at: https://digitalcommons.mtu.edu/etds

Part of the Civil Engineering Commons, and the Environmental Engineering Commons 


\title{
ASSESSMENT OF SEISMIC DAMAGE OF BUILDINGS AND RELATED ENVIRONMENTAL IMPACTS
}

By

Carley A. Feese

\begin{abstract}
A THESIS
Submitted in partial fulfillment of the requirements for the degree of MASTER OF SCIENCE

In Civil Engineering
\end{abstract}

MICHIGAN TECHNOLOGICAL UNIVERSITY

2013

(C) 2013 Carley A. Feese 
This thesis has been approved in partial fulfillment of the requirements for the Degree of MASTER OF SCIENCE in Civil Engineering.

Department of Civil and Environmental Engineering

Thesis Advisor: $\quad$ Dr. Yue Li

Committee Member: $\quad$ Dr. William Bulleit

Committee Member: $\quad$ Dr. R. Andrew Swartz

Committee Member: Mrs. Lynn A. Artman

Department Chair: $\quad$ Dr. David Hand 


\section{Table of Contents}

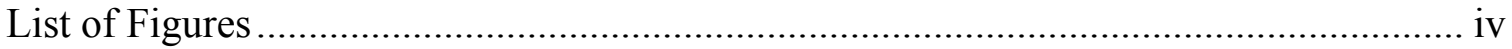

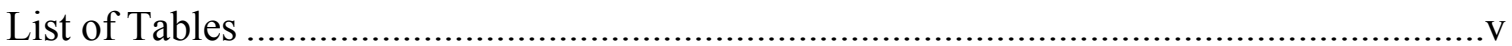

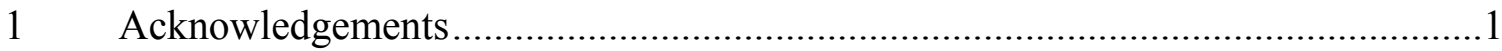

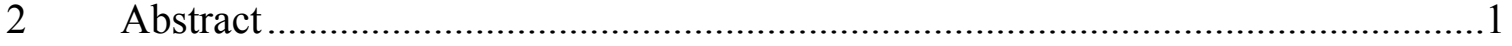

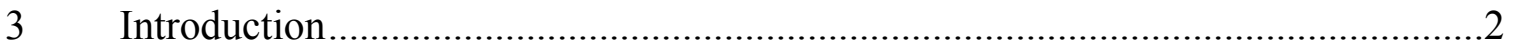

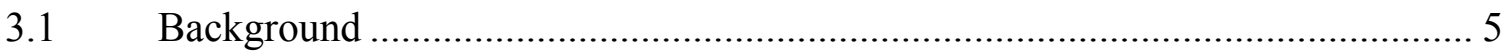

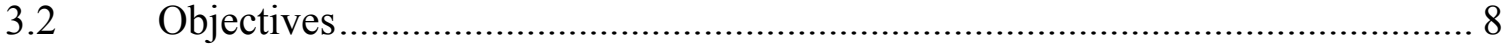

3.3 Life-Cycle Assessment (LCA) for Buildings ................................................. 9

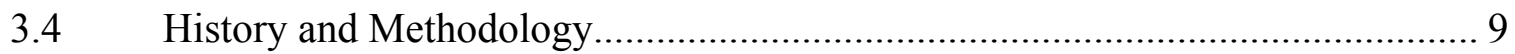

3.5 Past Life-Cycle Studies for Buildings ........................................................ 15

3.6 Earthquake Building Induced Damage .......................................................... 17

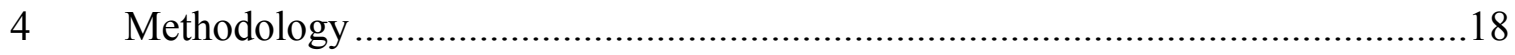

4.1 Athena Life-Cycle Analysis ...................................................................... 18

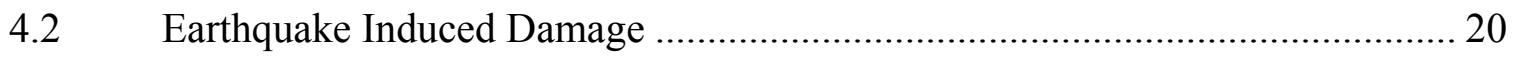

4.3 Incorporating Seismic damage in a Life-Cycle Assessment .............................. 25

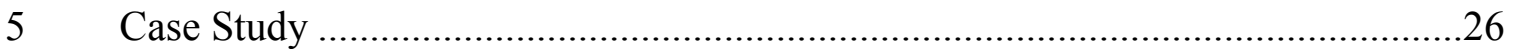

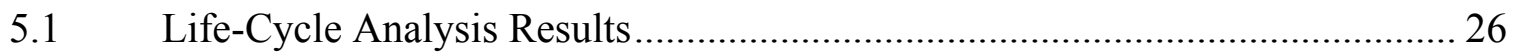

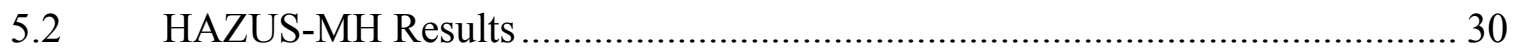

5.2.1 Steel Building HAZUS-MH Results.................................................... 30

5.2.2 Concrete Building HAZUS-MH Results ............................................... 33

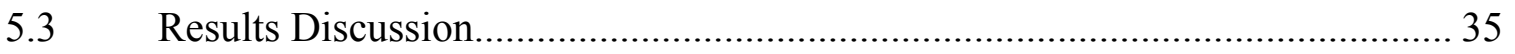

6 Building Energy Consumption when Subjected to Seismic Events .........................35

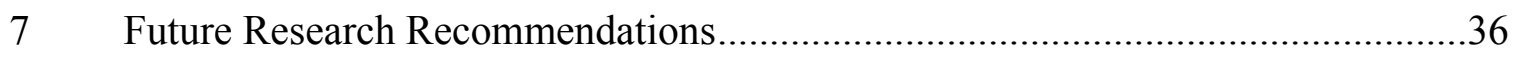

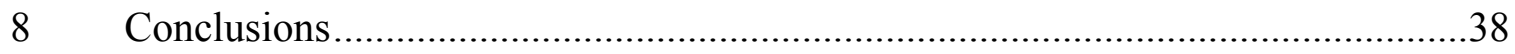

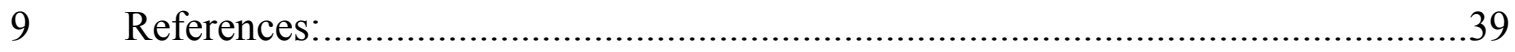




\section{List of Figures}

Figure 1: HAZUS-MH: Los Angeles, CA Building Inventory Data ................................. 23

Figure 2: Athena Results: Fossil Fuel Consumption Comparison................................... 27

Figure 3: Athena Results: Global Warming Potential Comparison.................................. 27 


\section{List of Tables}

Table 1: Repair Cost Ratios for each Damage State (HAZUS Technical Manual) ......... 24

Table 2: Case Study Building - Athena Input Data .................................................... 26

Table 3: Athena Eco-Calculator LCA Results............................................................ 28

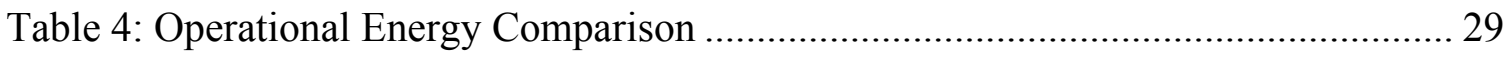

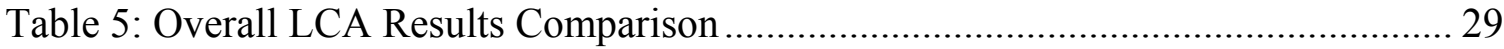

Table 6: HAZUS-MH Steel Data for Damage Cost Calculations .................................. 30

Table 7: Steel Building Damage Cost from Northridge Earthquake ................................ 31

Table 8: Steel Building Damage Cost from 100-Year Return Earthquake....................... 32

Table 9: Steel Building Annualized Seismic Damage Cost............................................. 32

Table 10: HAZUS-MH Concrete Data for Damage Cost Calculations ............................ 33

Table 11: Concrete Building Damage Cost from Northridge Earthquake....................... 33

Table 12: Concrete Building Damage Cost from 100-Year Return Earthquake .............. 34

Table 13: Concrete Building Annualized Seismic Damage Cost .................................. 34

Table 14: Overall Life-Cycle Impacts Including Seismic Damage ................................ 36 


\section{Acknowledgements}

Foremost, I would like to express my sincere gratitude to my advisor Professor Dr. Yue Li for the continuous support of my master's study and research, for his patience, motivation, enthusiasm, and immense knowledge. His guidance helped me in my research and this thesis.

Besides my advisor, I would like to thank the rest of my thesis committee: Dr. William Bulleit, Lynn Artman, and Dr. Raymond Swartz for their encouragement, insightful comments, and critiquing. I specially want to thank Dr. Bulleit for working closely with me to complete this thesis.

I also want to thank my fellow degree student, Aerik Carlton, for peer reviewing and moral support on this research topic.

Last but not the least; I would like to thank my family: my parents Kathy and Craig Feese and my grandparents Joan and Steve Mclain for supporting me throughout my educational career.

\section{Abstract}

Sustainable development has only recently started examining the existing infrastructure, and a key aspect of this is hazard mitigation. To examine buildings under a sustainable perspective requires an understanding of a building's life-cycle environmental costs, 
including the consideration of associated environmental impacts induced by earthquake damage. Damage repair costs lead to additional material and energy consumption, leading to harmful environmental impacts. Merging results obtained from a seismic evaluation and life-cycle analysis for buildings will give a novel outlook on sustainable design decisions. To evaluate the environmental impacts caused by buildings, long-term impacts accrued throughout a building's lifetime and impacts associated with damage repair need to be quantified. A method and literature review for completing this examination has been developed and is discussed.

Using software Athena and HAZUS-MH, this study evaluated the performance of steel and concrete buildings considering their life-cycle assessments and earthquake resistance. It was determined that code design-level greatly effects a building repair and damage estimations. This study presented two case study buildings and found specific results that were obtained using several premade assumptions. Future research recommendations were provided to make this methodology more useful in real-world applications. Examining cost and environmental impacts that a building has through, a cradle-to-grave analysis and seismic damage assessment will help reduce material consumption and construction activities from taking place before and after an earthquake event happens.

\section{Introduction}

"Sustainable development aims to enhance the quality of life by improving the social, economic and environmental conditions for the present and future generations" (Menna 
et al. 2013). Today structural engineers are faced with the challenging task of balancing sustainable design practices with sufficient structural integrity for safety. Buildings consume vast amounts energy and natural resources to construct and maintain and, when natural hazard events (e.g., earthquakes) occur, buildings consume additional energy to repair sustained damage.

Buildings are one of the largest consumers of natural resources and account for a significant portion of greenhouse gas emissions that contribute to climate change (D.O.E. 1993). This statistic is driving sustainable design to become a priority for building owners and designers. The most widely accepted definition for sustainable development is from the Brundtland Report, "Sustainable development is development that meets the needs of the present without compromising the ability of future generations to meet their own needs" (World Commission on Environment and Development 1987). Important factors that motivate sustainable development are natural resource consumption, air emissions, and consumption of energy. "In the United States, the building sector accounted for about $41 \%$ of primary energy consumption in $2010,44 \%$ more than the transportation sector and $36 \%$ more than the industrial sector" (D.O.E. 2013). A Key aspect in sustainable development should consider the building sector's energy consumption and material production due to world energy shortages and associated anthropogenic environmental effects. Few studies have linked the relationship between natural hazard mitigation and a building's environmental impact. This study will provide more insight on the topic of environmental impacts inherent to buildings, including impacts from earthquake induced damages. 
Life-cycle assessments (LCA) for buildings have become a major advancement in the design process for engineers. Numerous LCA studies have been completed for many different building types, and while this is essential for sustainable design, this type of analysis only considers a building's construction, use, and end-of-life phases. To incorporate new views on a building's energy consumption and contribute to future research, this paper will explore the integration of the environmental impacts that buildings have including repair damages from potential natural disasters (e.g., earthquake). The motivation behind this research is largely driven by the worlds depleting natural resources and increasing environmental concerns as they relate to natural hazard mitigation.

Earthquakes cause billions of dollars in structural damages and cause numerous deaths. "The United States faces the possibility of large economic losses from earthquake-damaged buildings and infrastructure" (Folger 2011). FEMA estimated that, on average, earthquakes cost the U.S. over $\$ 5$ billion per year and, of that California, Oregon, and Washington account for approximately $\$ 4.1$ billion $(77 \%)$ of this total estimated average annualized loss (Folger 2011). Several studies have examined structural building schemes and their resiliency to earthquake events; and while this examination is rightfully needed, this does not consider the environmental impacts incurred by repair and damage costs. While both natural hazard mitigation and LCA evaluations have evolved over the past years, they are not closely related. Only limited research has linked the two concepts, though they both strongly relate to sustainable design. 
Sustainable development is an issue recognized worldwide, and only recently has attention been directed towards the built infrastructure (i.e., buildings). Sustainable development has been a significant motivator and cause for the LCA methodology. LCAs give key considerations for evaluating environmental impacts produced by buildings throughout their life-cycle. Low impact buildings most commonly rely on advanced design techniques and innovative material technologies; both of which require additional upfront financial and environmental investments. Added seismic resiliency could, however, become a relief if an earthquake event was to occur, and this would justify the initial investments favoring sustainable design consideration as a positive cost benefit (Comber et al. 2012). LCA studies consider all stages of a building's lifespan including; initial construction, maintenance, and energy usage. Not often do they consider the impacts caused by natural disaster events. This is an opportunity for structural engineers to communicate the importance of a building's seismic risk, and to employ mitigation strategies that minimize a building's life-cycle impact with these potential risks in mind.

\subsection{Background}

A study completed by Menna et al. (2013) presented a novel approach of including induced seismic damages in their LCA of a building. Menna et al. (2013) study methodology determined probabilities of exceeding a set of structural damage limit states during the infrastructure's lifetime to determine repair damage costs. The environmental implications were calculated taking into account the determined initial building construction environmental effects. Menna et al. (2013) concluded that the seismic events 
influenced the LCA $6 \%$ when considering the whole building's environmental impact and $25 \%$ when compared to the initial construction phase.

Taghavi and Miranda (2003) determined that in a typical building the structural system accounts for approximately $10-20 \%$ of the construction cost. Although this structural system is a small portion of the total building cost, upgrades to the system could lead to cost savings after experiencing an earthquake. "Hence, given the significance of the damaged-based repair costs, achieving a higher performance level for the building may play a fundamental role in reducing the overall life-cycle costs," (Menna et al. 2013).

Tapia and Padgett (2012) organized a literature review on the perspectives of linking natural hazard risk mitigation and sustainable engineering. "Although most definitions of sustainable development do not explicitly mention natural hazard risk mitigation, its consideration cannot be excluded" (Padgett and Tapia 2012). The study indicates that the Federal Emergency Management Agency (FEMA 2002) infrastructure natural hazard mitigation practices also supports the triple bottom line of sustainability; by preventing harm to the environment, economy, and society overall. Preventing earthquake induced damages will not only save lives and discomfort to local residents, but will help the economy and ultimately preserve natural resources and economic challenges due to repair. "Several studies have considered life-cycle performance of structures under joint natural hazards and aging" (Padgett and Tapia 2012), but most however, do not analyze results in terms of environmental impacts.

The Structural Engineers Association of California (SEAOC) represents the structural engineering community and states in their Blue Book that seismic design is, "primarily to 
safeguard against major structural failure and loss of life, not to limit damage or maintain function". Therefore, a building designed using code minimums does not necessarily ensure consideration of the whole building's life-cycle impacts and the consequences of damage and repair (Kneer and Maclise 2008). Kneer and Maclise (2008) summarized and completed case studies examining the role that building performance has in minimizing the environmental impacts for buildings located in areas of seismic risk and has also summarized available software tools. Kneer and Maclise (2008) suggest additional case studies are needed to expand and increase the robustness of research concerning LCAs. Software such as HAZUS-MH (FEMA 2002), a performance based design tool, and Athena (Athena 2013), a LCA tool, were both recommended.

A study written by Comber et al. (2012), examined the need to "shift away from designing code-minimum buildings that are life-safe but often disposable", and presented a method that examines a building's long term environmental impacts including expected seismic damage. The authors completed a comparative study examining two case study buildings, a concrete moment frame and a shear wall system, and determined that the moment frame had a lesser total carbon equivalent emissions. The study also concluded that the moment frame would require $19 \%$ of the building's total embodied energy to repair damages, and the shear wall system would require $15 \%$. The study determines that although the shear wall system did have more associated carbon outputs when considering its total embodied carbon output, the difference between the two when considering their carbon output caused from seismic repair is much more substantial. A project that has a greater initial investment and increased carbon outputs due to structural choices will ultimately reduce carbon outputs caused by repair damages after an 
earthquake event. The study concludes by giving future recommendation for the structural community to explore this idea of determining the environmental implications of performance-based and disaster-resilient design (Comber et al. 2012). The authors also suggest that LEED, or other environmental rating systems, give incentives for disaster resilient design strategies in order to reach environmental performance objectives.

\subsection{Objectives}

The objective of this paper is to explore the differences between steel and concrete framed buildings, pairing results from a LCA and seismic damage analysis. The challenge of quantifying the environmental impacts due to buildings and seismic damage will be approached in two separate analyses. This thesis will first compare the two building frame types using the LCA method and then use HAZUS-MH to determine potential damage and repair costs under various seismic events. The environmental impacts between the two will be integrated, giving a total environmental impact of a building that is located in a seismically prone area. This study will examine the damage and repair costs explicitly caused by each building's structural components; this will make for a clear comparison between the two building materials, steel and concrete. Although this comparison between steel and concrete is completed, the method approach described throughout this paper can be used for all building types. This type of building examination can assist building owners and engineers to choose between building designs, and ultimately lead to environmentally conscious and seismically resilient design choices. 


\subsection{Life-Cycle Assessment (LCA) for Buildings}

Buildings in the United States consume a significant amount of energy and natural resources, causing environmental impacts to the world. "In the United States, 54\% of energy consumption is directly or indirectly related to buildings and their construction," (Horvath 2002). It is apparent that analyses on building materials and their environmental impact is essential in order to compare various design options, improve existing practice, and to recognize opportunities for environmental improvements. To date, life-cycle assessment (LCA) provides the most complete framework for aiding in the decisionmaking-processes needed to accomplish substantial environmental improvements. Lifecycle assessment, also known as life-cycle analysis, or cradle-to-grave analysis, is a tool used to assess a building's environmental impact. A LCA takes a broad overview of a building's life-span and assesses potential environmental impacts at different life-cycle stages.

\subsection{History and Methodology}

"LCA methodology was first established in 1990 by the Society of Environmental Toxicology and Chemistry (SETAC) and was then later formalized in 1997 by the International Standards Organization (ISO) as a way to assess the environmental impacts of a product system", (Johnson 2006). According to the ISO standards, the LCA method is "a technique for assessing the environmental aspects and potential impacts associated with a product" (ISO 14040 1997). A complete LCA of a building includes material 
extraction, processing and manufacturing, construction, use, end-of-life, and transportation impacts related to all of these stages. A broad set of environmental impacts can be found using the LCA analysis method such as, global warming potential, resource depletion, toxicity, and ozone depletion.

There has been debate over the use of LCA as a decision-making tool, because the results vary from one analysis to another. Results can be misinterpreted and input-output models can misrepresent a physical building. Due to the vast data collection and interpretation techniques that a LCA can take on, various environmental organizations sought to standardize the LCA methodology. In early 1990's, the International Organization Standards Organization came into existence for the purpose of standardizing the LCA. ISO went through several publications and today there is one standard which was released in 2006 titled, "Environment Management - Life-cycle Principles and Management - Life-cycle Assessment - Requirements and Guidelines" (ISO 14044 2006, Johnson 2006). Each international standard was devised to help guide every LCA to be more accurate, and comparable creating more useful results.

A complete LCA consists of four phases and that are defined by the International Standard for Environmental Management. The goal and scope, guide the assessment method to ensure that the results are usable and realistic. Additionally the goal needs to define motives for completing the LCA and express results for specific audiences. The explanation of scope for a LCA should outline what stages of the building's life-cycle are to be included in the study and why they were chosen. The ISO 14040 (2006) recommends a range of different components to be considered when completing an LCA such as: the functional unit, the functions of the system, data requirements, impact 
categories, methodology of the impact assessment, and interpretation. The scope defines the functional unit of what is to be analyzed, how it is going to be analyzed, and how it is to be interpreted. The data requirements needed in the goal definition and scope phase are related to data quality. Considerations for data quality include the age of the data, the geographic location that the data is collected from, the variability in data values, the comprehensiveness of the data set, the technologies associated with each data input, and the source of the data findings. These listed factors can affect the input data and can skew the results obtained from a standardized LCA.

The inventory phase includes the collection of all data needed for environmental calculations. Examples of LCA inputs may include energy, water, land use, and natural resources. Outputs may include harmful environmental emission into the air, land or water, and use of non-renewable resources. The inventory phase is the most time consuming aspect of a LCA. Ultimately a complete LCA will include every input necessary for a building's life-cycle and include every output that exists within its lifetime.

The impact assessment phase assigns a numerical value to the environmental impacts. The main intention of impact assessment phase is to consider the relative magnitude and significance of each environmental impact considered, based on the inputted and outputted material data collection. Impact assessment, requires the selection and definition of impact categories, classification, characterization, normalization, grouping, weighting, and data quality analysis. All environmental impacts that are alike can be grouped together by classification and manipulated from the above list to define which impacts are the most significant. Examples of impact categories are global warming, 
depletion of minerals and fossil fuels, human toxicity, ozone depletion, land use, and water use. Common impact classifications for impact categories could be global warming, resource depletion, land use, eutrophication, etc. Characterization converts the category indicator results into common units, and is completed in order to make comparisons among many different environmental impacts easier. For example, the carbon emissions most commonly reported from a $\mathrm{LCA}$ is given in $\mathrm{CO}_{2}$ equivalents. All inputs and outputs that contribute to a building's overall greenhouse gas emissions are multiplied by a $\mathrm{CO}_{2}$ equivalence or characterization factor. The conversion allows the user to compare different inputs and outputs with a common greenhouse gas unit. Normalization involves dividing the indicator results by a selected reference value. For instance, these results can be compared on a per capita basis or a per unit basis. This allows a user to compare the environmental effects more readily. Weighting involves multiplying the impact categories by factors that relate to their importance or significance by considering the environmental consequence, however this can be subjective.

The interpretation phase and the last phase in a complete LCA, interprets the determined impact results. The user can identify significant contributors to a building's overall environmental impact, draw conclusions, and determine associated limitations, to assist in future recommendations for environmental considerations.

Life-cycle assessments group a building's lifespan into separate phases, initial construction, usage, and end of life. The initial construction phase, also known as a building's embodied energy, includes material extraction, manufacturing, assembly and transportation impacts related to each. The use phase, also known as the operational energy usage phase, requires the analyst to estimate a building's anticipated energy usage 
over an assigned period of time. Usually maintenance and repair data is included in the use phase. The last life-cycle stage considered in a complete LCA of a building includes the end-of-life phase. The related data with demolition and solid waste activities are inputted. Each stage needs to be considered when complete a full LCA of a structure.

LCA has become common and is increasingly being used as a design aid, and is capable of providing decision-makers the ability to weigh environmental benefits of one design over another. And, although one LCA can be considerably different from one building to another, both have the same underlying intentions of reducing a building's overall environmental impact.

An ever popular use for LCA is in union with the Leadership in Energy and Environmental Design (LEED). The US Green Building Council defines LEED as "a voluntary, consensus-based, market-driven program that provides third-party verification of green buildings". More and more owners and designers are increasingly aware of LEED certification. LEED focuses on reducing a building's environmental impact considering its initial construction, as well as reducing a building's operational energy usages (LEED 2013).

Life-cycle assessments are still in development, and although it has been a great improvement for making sustainable design choices, the general understanding of its methodology is lacking. The question of what are the appropriate input-output models and interpretation techniques still needs to be fully established for more accurate LCA results. Such uncertainties and limitations include geographic issues, availability and quality of life-cycle inventory data, and interpretation of results. 
Geographic limitations and uncertainties is a concern for all LCAs conducted on different building systems. A building's location can affect how a certain material is extracted, manufactured, and eventually assembled. The same material used at different construction sites can greatly change the environmental contribution due to dissimilar types of energy fuels used for similar materials in different locations. Buildings consume vast amounts of materials; tracking these material's origins and trying to include all material inputs can be difficult and influence the LCA results.

The availability and quality of life-cycle inventory data can vary greatly from one study to another, and involves the collection of a wide range of materials from a variety of services. Accurately collecting the data can be very time consuming and costly to acquire such data. Not only can location affect data input and output, but the time that the data was collected. Technology used to distribute, manufacture, and assemble is constantly changing and can affect the environmental impact.

Several LCA computer software programs are obtainable out on the market. Each software program assists in the input-output collecting inventory phase and additionally allows for better interpretation of the results. Athena Impact Estimator, a LCA software tool, allows a user to complete a whole building LCA. The user can input building type assemblies and a building's location. The Athena software has built-in material databases and uses this in its LCA calculation. Each stage of a building's life-cycle can be examined and includes raw materials, material manufacturing, transportation, on-site construction, operational energy consumption, maintenance, repair and replacement, demolition and disposal. However, the user cannot input specific material quantities, because the software uses pre-set assumptions based on average building assemblies and 
this input data cannot be changed or altered by the user. Athena allows for quick analyses on buildings that do not have detailed material inputs (Athena 2013).

\subsection{Past Life-Cycle Studies for Buildings}

Guggemos and Horvath (2005) completed a comparative study between a concrete frame structure and a steel frame structure, isolating each of the LCA stages. Both structural frames were designed to model typical office buildings, located in the Midwestern U.S. with a projected lifespan of 50 years. The buildings shared interior finishes, painted partition walls, built-up roofing, and concrete matt foundations, having only their structural frame varying. Guggemos and Horvath determined the steel frame structure was more costly than the concrete framed structure, using R.S. Means (1999) for their cost estimates. The authors compared the two structural frames at two levels, initial construction phase and overall LCA. The study determined that during the construction phase, the concrete structural frame had greater associated energy use and $\mathrm{CO}_{2}$ emissions, mainly due to the fact that concrete uses more temporary materials, longer installation time, and transportation impacts then does steel. The study additionally determined that the overall life-cycle comparison of both buildings seemed to have very similar environmental impacts (Guggemos and Horvath 2005).

A building's energy consumption is divided into embodied energy and operational energy. Embodied energy is the amount of energy used to construct, maintain, and dispose of a structure. This includes the impacts from obtaining the raw materials, the processes these materials go through, the assembly of these materials, the maintenance 
and operations required to maintain those materials, the effects of disposing the product after its useable life-span, and includes transportation impacts related with each. A building's operational energy is the usage energy that includes heating, water, airconditioning, and lighting. Cole and Kernan (1996) determined that about $80 \%$ to $90 \%$ of a building's energy usage is accredited to the operational energy alone. Their study analyzed three separate structural systems: wood, steel, and concrete and then compared their embodied and operating energy use. Each building was modeled as a typical office building and compared each structural frame. The study determined that the steel building had a greater reoccurring embodied energy than that of the concrete structure and additionally determined that the wood frame had the least lifespan energy usage and that steel had the greatest lifespan energy usage. The study recognizes that, "An important conclusion is that published studies on initial embodied energy of buildings provide a guide to the typical ranges for the initial embodied energy of office buildings, however it is difficult to interpret and compare studies in any detail because of the lack of definition of what was included within the total embodied energy figures" (Cole and Kernan 1996). The study also came to the conclusion that the operational energy usage in buildings represents the largest component of life-cycle energy usage. "As environmental issues continue to become increasingly significant building design priorities, we can anticipate considerably improved energy standards," (Cole and Kernan 1996). And, as the operational energy is decreased, more attention will be drawn to reducing a building's embodied energy. The study also suggests that reducing a building's embodied energy involves much more than comprehensive design approaches, it also involves examinations into a building's repair and replacement costs. The study ends by 
suggesting that future research focus on material longevity and the ability to replace elements within a total building assembly.

\subsection{Earthquake Building Induced Damage}

Earthquakes can be devastating events and cost billions of dollars in repair. As engineers, our understanding of earthquakes has had much improvement over the past twenty years. This is mainly due to the fact that the technology to track and collect data on seismic events has greatly improved. All data is collected and shared globally, giving scientists and researchers the opportunity to build more complete models of the earth's ground motion due to seismic events and use this information to design safer buildings. The United States Geological Survey (USGS) stated that "In 1931, there were about 350 stations operating in the world; today, there are more than 8,000 stations and the data now comes in rapidly from these stations by electronic mail, internet and satellite". Major earthquake events like San Fernando (1971), Loma Prieta (1989), and Northridge (1994) has given engineers numerous seismic data for analyzing future earthquake occurrences and understanding structural responses.

Estimating potential damage that a building will experience under a given earthquake event is a challenging task, several studies have turned to computer software programs to help estimate anticipated seismic damage to buildings. HAZUS-MH, a nationally accepted computer software program, that estimates potential losses from earthquakes, floods, and hurricanes can ease this challenging analysis (FEMA 2002). FEMA developed HAZUS-MH with the National Institute of Building Sciences (NIBS) to help 
aid in hazard mitigation. Up-to-date and current engineering and scientific knowledge are used in the program to assess loss estimates for earthquake hazard events. HAZUS-MH has default databases that include data regarding building inventory and demographics for all regions located in the United States (Kircher et al. 2006). The program provides historical data of past seismic events that have occurred in the U.S. and additionally allows one the ability to create a theoretical event. When a user inputs a certain earthquake event, the Potential Earth Science Hazard (PESH) module estimates ground motion and ground failure. The ground motions and ground failure are estimated based on the fault type, location, and earthquake magnitude; each of which can be selected by the user. After an earthquake scenario is created, a direct damage module is created that estimates the damage in terms of probability of exceeding states of set damage for any given ground motion or failure.

\section{Methodology}

\subsection{Athena Life-Cycle Analysis}

A number of LCA software tools were examined by the author and Athena EcoCalculator (AEC) was chosen, explicitly because of the lack of material and quantitytake-off data needed for each case study building. Athena LCA software has two LCA calculators available, the Athena Eco-Calculator and the Athena Impact Estimator (AIE) (Athena 2013). AEC allows a user to complete a whole building LCA by allowing the user to input building type assemblies and location. The program has built-in material databases for each stage of a building's life-cycle that can be examined; and includes 
raw materials, material manufacturing, transportation, on-site construction, maintenance, repair and replacement, demolition, and disposal. The AEC is similar to the AIE, however the AEC does not included operational energy usage (Athena 2013). A complete LCA for each case study building will be accomplished by using the AEC for the environmental impacts caused by initial construction and end of life impacts and will utilize the AIE to determine each building's operational energy impacts.

The Athena Eco-Calculator requires square footages for each assembly that is included within the LCA such as: foundation and footings, columns and beams, intermediate floors, exterior walls, windows, interior walls, and roof. The AEC outputs environmental impacts including the following: fossil fuel consumption, global warming potential, acidification potential, human health respiratory effects potential, eutrophication potential, ozone depletion potential, smog potential, and weighted resource use. AEC impact categories are set forth by the US Environmental Protection Agency for LCA and are in accordance with ISO 14040 (Athena 2013). This thesis will examine fossil fuel consumption and global warming potential differences between the two case study buildings.

The AIE was utilized to determine each building's operational energy usage. The operational energy between both buildings was determined assuming that each building consumes the same amount of energy per year. Cole and Kernan (1996) states that, "The difference in the operating energy between wood, steel and concrete framed buildings is negligible". The two case study buildings within this study have the same internal building materials having only their structural frame varying thus this assumption is accepted and utilized. The AIE allows the user to input the location and estimated fuel 
consumption quantities, such as natural gas and electricity consumption per square floor area annually. After providing the building's location and consumption the software generates the appropriate electricity grids, transportation modes and distances, and product manufacturing technologies that affects the building's environmental impact. The assumption for energy consumption for both case study office buildings, located in the U.S., use $183 \mathrm{kWh}$ per square meters, annually and 10 cubic meters of natural gas per square meters annually (D.O.E. 1983). The annual consumption data was entered into Athena Impact Estimator and the operational energy impacts were obtained.

\subsection{Earthquake Induced Damage}

"HAZUS-MH, Hazards United States Multi-Hazard, a comprehensive software tool developed by the Federal Emergency Management Agency (FEMA) of the United States through the National Institute of Building Sciences (NIBS), to determine multi-hazard loss estimations in the United States on a regional basis" (Ploeger et al. 2010). HAZUS earthquake has two building damage functions; capacity curves and fragility curves. Each function is given for low, medium, or high rise buildings of varying type (i.e., steel, concrete). The capacity curves are based on a structures yield limit and ultimate strength and characterize the nonlinear (pushover) structural behavior. For each building type the capacity parameters change and illustrate the different levels of seismic design and anticipated seismic performance. Fragility curves describe the probability of damage to a structural system and its non-structural components (sensitive to drift or acceleration). Fragility curves are a good indicator of how a structure will withstand a seismic event 
and can give insight into damage and repair costs due to certain ground motion events. For a given building type and its response, fragility curves distinguish damage between four main categories; slight, moderate, extensive, or complete. Defining the damage states in this way allows for easier communication and calculation for damage and repair costs. Evaluating how different code standards and building types affect a structures resistance to varying earthquake events will illustrate to engineers the importance of performance-based design.

The damage functions within HAZUS are based on three seismic design code levels, high, moderate, low, and pre-code. The pre-code design level represents structures built before 1941 when seismic codes were not required for buildings located in seismically active regions. High, moderate, and low code design levels are based on 1994 Uniform Building Code, lateral force design requirements of seismic zones 4, 2B, and 1, respectively (FEMA 2002). Buildings built after 1975 are considered to be high seismically designed and buildings built between 1941 and 1975 are considered to be moderately designed.

The seismic events that were chosen for analysis in this study are Northridge, 100year event, and an annualized damage analysis for a building located in Los Angeles, California. On January 17, 1994, a 6.7 magnitude earthquake hit San Fernando Valley. Northridge earthquake caused sixty peoples deaths, 7,000 injuries, and left 20,000 people homeless in Los Angeles, Ventura, Orange and San Bernardino Counties (USGS 2013). The total damage cost estimate was between 13 and 20 billion U.S. dollars (USGS 2013). Because of the severity of this damage and its location, this event was chosen to model the most damage that could occur to a building under a single earthquake event. 
The 100-year return provides an estimate of the likelihood of a certain magnitude event occurring. For a 100 -year return event this has $0.01 \%$ probability of occurring in any given year during a building's lifetime. HAZUS-MH uses a default value of magnitude 5 earthquake for the 100-year event scenario.

The annualized earthquake loss estimation that was determined using HAZUS-MH is the estimated long-term value of earthquake damages and losses to the general building stock in any single year in a specified geographic area (FEMA 2008). HAZUS-MH takes into account such factors as historic patterns of frequent smaller earthquakes with infrequent but larger events, and provides a balanced estimate of potential earthquake damage. This allows one to compare buildings built to different codes that are located in different regions around the country (FEMA 2008).

The two theoretical buildings within this study are location in Los Angeles County which consists of approximately 4,083 square miles, and includes 1,652 census tracts (Kircher et al. 2006). The default inventory data included in HAZUS-MH for the Los Angeles County region is shown in Figure 1. For each design level and structure type, HAZUS-MH provides the default inventory building count. The total building count value shown in Figure 1 includes all building types; i.e. wood, steel, concrete, precast, reinforced masonry, unreinforced masonry, and manufactured homes. As shown steel and concrete building types is a small portion of the overall building inventory for this area. Other buildings could be examined within HAZUS-MH to understand their seismic resiliency and environmental impact. 


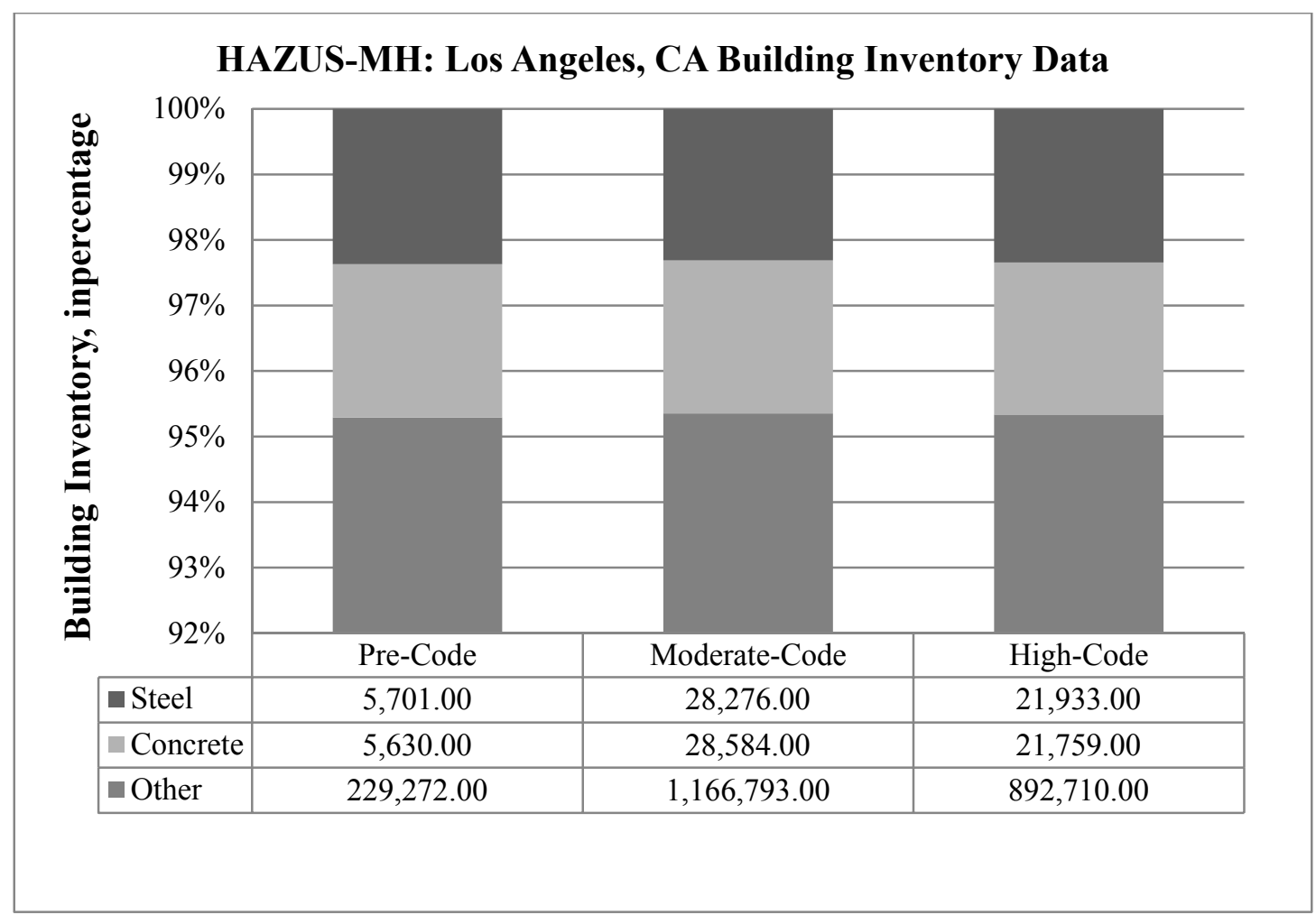

Figure 1: HAZUS-MH: Los Angeles, CA Building Inventory Data

HAZUS determines the probability of damage to the general building inventory, and converts these probabilities into number of damaged buildings under the four damage states. This study uses these probabilities of damage to the general region of different building types to describe the damage that would occur to an individual building.

The total probability of damage to the general population of steel and concrete buildings was determined for each of the previously mentioned earthquake events. The probability of damage was provided for each of the four damage states, each building type, and design code. HAZUS-MH technical manual provides structural repair cost ratios in percent of building replacement costs for each damage state and building type. For this analysis it was assumed that both building types under consideration were COM4 in the HAZUS-MH technical manual (FEMA 2013). COM4 is a group of buildings that 
are considered to be generic professional business offices (FEMA 2013). While HAZUS does give a cost estimate for COM4 building type a more up-to-date cost estimate for each of the steel and concrete framed structures was used. REED Construction Data Inc., an online source, provided a cost estimate for each the building type. REED Construction Data Inc. considered each structure to be 4 story (each story being 10 feet) office buildings located in Los Angeles, California, and additionally having a total floor area of 86,400 square feet. The REED building cost estimates are derived from a building model, built in 2013, and assumes basic components and does not include a basement. It was estimated that the steel building's approximate cost is $\$ 225.25$ / SF and the approximate cost for the concrete building type is $\$ 183.87 / \mathrm{SF}$ (REED 2013). Both of these cost estimates were used when calculating the damage cost related to the percent damage based on the different probabilities and their associated damage states.

For building type COM4, Table 1 below, presents the associated structural damage state and their associated structural repair cost ratios. The structural repair cost ratio relates building damage to total cost of the building.

Table 1: Repair Cost Ratios for each Damage State (HAZUS Technical Manual)

\begin{tabular}{|c|c|}
\hline $\begin{array}{c}\text { Structural Damage } \\
\text { State }\end{array}$ & $\begin{array}{c}\text { Structural Repair Cost Ratios } \\
\text { (in \% of building's replacement cost) }\end{array}$ \\
\hline Slight & 0.4 \\
\hline Moderate & 1.9 \\
\hline Extensive & 9.6 \\
\hline Complete & 19.2 \\
\hline
\end{tabular}

The structural repair cost ratios and the buildings total cost led to the calculation to determine the cost of damage under each of the different damage states. 


\subsection{Incorporating Seismic damage in a Life-Cycle Assessment}

To calculate the environmental impacts caused by seismic damage, this study related the building's embodied energy to cost and used this relation to determine the cost of damage and environmental impact for repairs. HAZUS-MH provided the damage probabilities for each damage state, which were then multiplied by each of the structural damage ratios and summed for all the separate damage states to obtain each building's total probability of damage. The total sum of damage probability was then multiplied by the total cost of the building to obtain the total cost of damage. To relate cost to energy the AEC results for each building was divided by its total cost, to obtain the energy in mega joules per dollar. This relationship was used in determining about much energy each event would consume for repair damages.

The two single events that were analyzed in HAZUS-MH (i.e. Northridge and 100year event) would merely just contribute to a building's overall LCA impact. This study examined HAZUS-MH annualized loss to get a per-year potential damage estimate for each building type. The annualized damage was multiplied by the estimated lifespan of each building to represent 60 years' worth of seismic damage that each structure could possibly experience. The annual seismic damage cost was additionally converted into mega joules of energy and summed with the overall lifecycle impact of each building. This method could overestimate damage in some years but could also underestimate damage in other years. 


\section{Case Study}

\subsection{Life-Cycle Analysis Results}

The two case study buildings under consideration were modeled as low-rise commercial buildings, located in Los Angeles, California. Both office buildings were analyzed as 4 stories, with each story height being 10 feet. Each story has a floor area of $120 \mathrm{ft}$. by 180 ft., giving a total floor area of 86,400 square feet. Both office buildings were assumed to share the same foundations, interior walls, and window material, and thus these items were not included in the environmental comparison. The structural elements in a building have a greater environmental effect because they have the greatest percentage of material quantity to the whole building envelope (Delong et al. 2011). Table 2 provides each assembly type and area that was inputted into the Athena Eco-Calculator program.

Table 2: Case Study Building - Athena Input Data

\begin{tabular}{|c|c|c|c|c|}
\hline Assembly & Steel Building & $\begin{array}{c}\text { Concrete } \\
\text { Building }\end{array}$ & Input & Units \\
\hline $\begin{array}{c}\text { Columns } \\
\text { \&Beams }\end{array}$ & HSS column / WF beam & $\begin{array}{c}\text { Concrete Column } \\
\text { / Concrete Beam }\end{array}$ & 86,400 & SF \\
\hline $\begin{array}{c}\text { Intermediate } \\
\text { Floors }\end{array}$ & steel joist & $\begin{array}{c}\text { Suspended } \\
\text { Concrete Slab }\end{array}$ & 64,800 & SF \\
\hline $\begin{array}{c}\text { Exterior } \\
\text { Walls }\end{array}$ & $\begin{array}{c}\text { steel cladding (26 ga) } \\
\text { R - 3.8 continuous } \\
\text { insulation sheathing, } \\
\text { 2x4 steel stud 24" o.c. }\end{array}$ & $\begin{array}{c}\text { Precast Concrete } \\
\text { Cladding - Cast in } \\
\text { place Concrete } \\
\text { Continuous } \\
\text { Insulation + Latex } \\
\text { Paint }\end{array}$ & 19,080 & SF \\
\hline Roof & $\begin{array}{c}\text { steel roofing system R- } \\
\text { 20 continuous } \\
\text { insulation + } \\
\text { polyethylene } \\
\text { membrane, open-web } \\
\text { steel joist w/ steel } \\
\text { decking, gypsum board } \\
\text { + latex paint }\end{array}$ & $\begin{array}{c}\text { Suspended } \\
\text { Concrete Slab - } \\
\text { EPDM membrane } \\
\text { R-20 Continuous } \\
\text { Insulation }+ \\
\text { polyethylene } \\
\text { membrane }+ \\
\text { Latex paint }\end{array}$ & 21,600 & SF \\
\hline
\end{tabular}


The environmental impact results for both the concrete and steel generic building types are provided in Figure 3 and Figure 4 shown below.

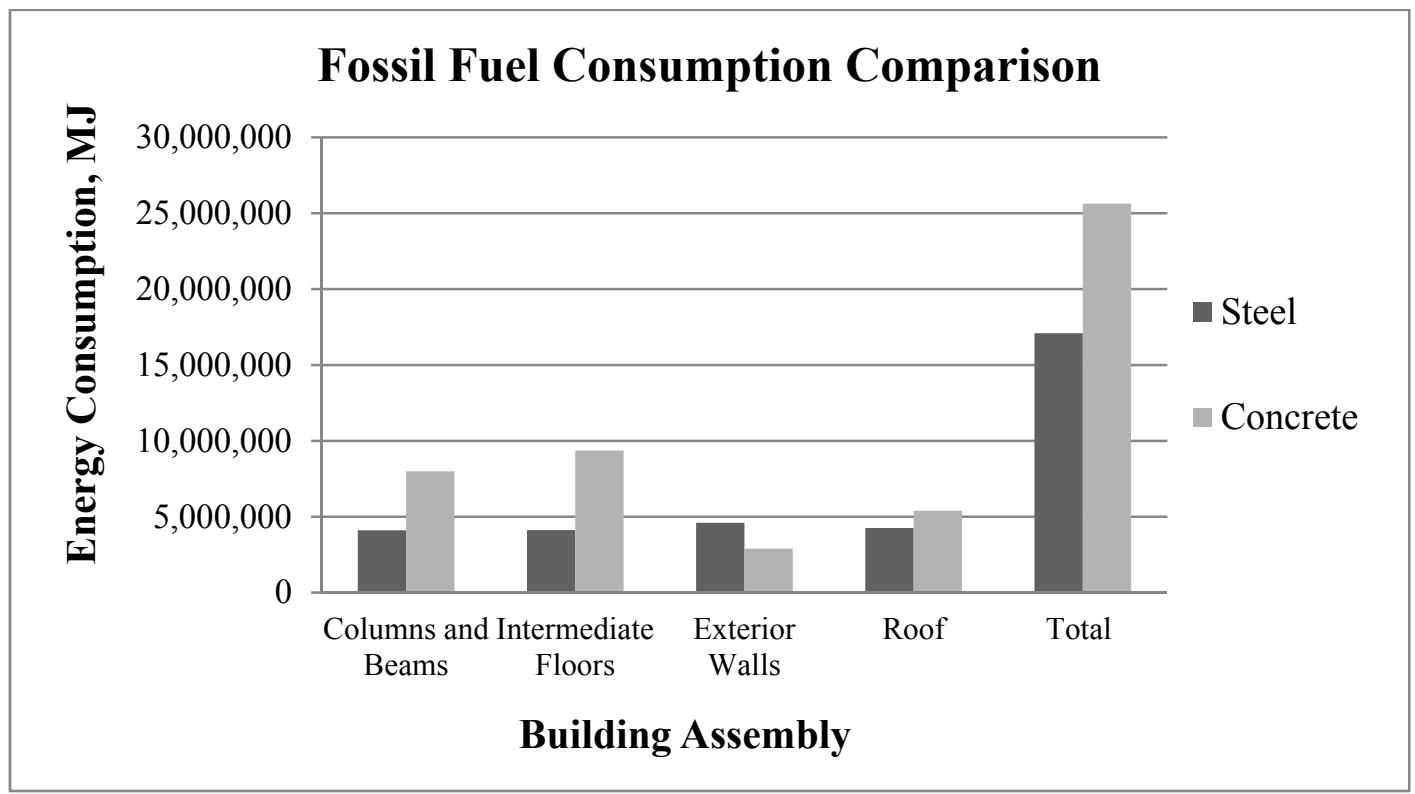

Figure 2: Athena Results: Fossil Fuel Consumption Comparison

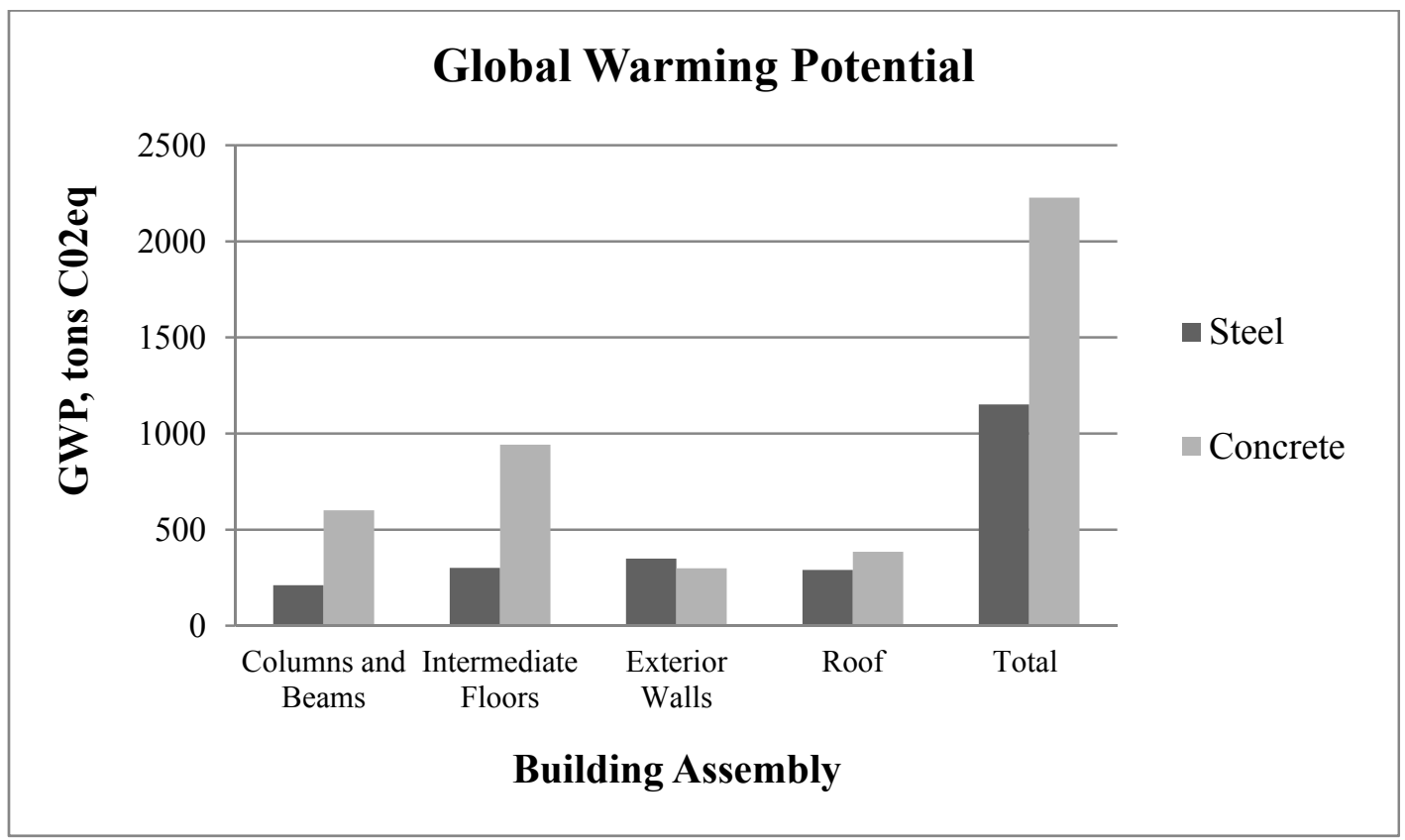

Figure 3: Athena Results: Global Warming Potential Comparison 
Table 3 provides the energy consumption and global warming potential in terms of energy or global warming potential per square feet for comparison purposes.

Table 3: Athena Eco-Calculator LCA Results

\begin{tabular}{|c|c|c|}
\hline Building Type & $\begin{array}{c}\text { Fossil Fuel } \\
\text { Consumption } \\
\text { (MJ / SF) }\end{array}$ & $\begin{array}{c}\text { GWP } \\
\text { (ton CO2 } \mathbf{C q} \text { / SF) }\end{array}$ \\
\hline Steel & 197.78 & 0.013 \\
\hline Concrete & 296.73 & 0.026 \\
\hline
\end{tabular}

The differences between the generic steel and concrete building's energy consumption, not including each building's operational energy illustrates that steel has less of an impact. It was determined that the steel building has a lower fossil fuel consumption and global warming potential when compared to the concrete building. However, this could be due to the material assembly choices that were made within AEC. The results obtained from AEC were made using several pre-made assumptions that should be considered. A more rigorous analysis on detailed building assembly components should be made if this method was used in a real-world design project.

The operational energy results given from AIE are shown below in Table 4. The results depict how location affects the calculated operational energy usages. The methods used to extract, refine, and distribute energy to buildings varies throughout America. Guggemos and Horvath (2005) operational energy was shown for comparison purposes to the AIE estimate energy consumption. The results are similar due to the fact the both this study and Guggemos and Horvath's (2005) study had similar usage inputs. 
Table 4: Operational Energy Comparison

\begin{tabular}{|c|c|c|}
\hline Study & $\begin{array}{c}\text { Energy } \\
(\mathrm{MJ} / \mathrm{SF})\end{array}$ & $\begin{array}{c}\text { Description of } \\
\text { Location }\end{array}$ \\
\hline Athena Impact Estimator & 9214 & USA \\
\hline Athena Impact Estimator & 8751 & Los Angeles, California \\
\hline Guggemos et al. (2005) & 6862 & Midwest U.S. \\
\hline
\end{tabular}

Table 5 provides each structure's operational energy and embodied energies.

Table 5: Overall LCA Results Comparison

\begin{tabular}{|c|c|c|c|}
\hline $\begin{array}{c}\text { Building } \\
\text { Type }\end{array}$ & $\begin{array}{c}\text { Embodied } \\
\text { Energy } \\
\text { (MJ/SF) }\end{array}$ & $\begin{array}{c}\text { Operational } \\
\text { Energy } \\
\text { (MJ/SF) }\end{array}$ & $\begin{array}{c}\text { Total LCA } \\
\text { Environmental } \\
\text { Impact (MJ/SF) }\end{array}$ \\
\hline Steel & 198 & 8,751 & 8,949 \\
\hline Concrete & 297 & 8,751 & 9,048 \\
\hline
\end{tabular}

Approximately $98 \%$ of the total energy consumption was solely due to the operational energy when considering the overall LCA impacts for both building types. This data relates to Cole and Kernan (1996) findings, although operational energy is the main issue in a building's energy consumption, the intent of this research was to examine each building frame and their resiliency and impact when subject to seismic events. The implications and recommendations for future research will be discussed subsequently in the results discussion section of this paper. Possible alternatives to reduce a building's usage phase impacts could examine decreasing heating, lighting, and electricity usages. 


\subsection{HAZUS-MH Results}

\subsubsection{Steel Building HAZUS-MH Results}

Table 6 provides the calculated data that was used in the damage analysis for the steel building.

\section{Table 6: HAZUS-MH Steel Data for Damage Cost Calculations}

\begin{tabular}{|l|c|}
\hline Energy per Replacement Cost (MJ / \$) & $\mathbf{0 . 8 8}$ \\
\hline Total Cost Replacement Value (\$ / SF) & $\mathbf{2 2 5 . 2 5}$ \\
\hline Energy for Building, 60-year lifespan (MJ / SF) & $\mathbf{1 9 7 . 7 8}$ \\
\hline
\end{tabular}

Table 7 describes the damage to the general population of steel buildings if a Northridge event were to occur in the Los Angeles, CA area. For the general population of high designed steel buildings, HAZUS-MH estimates that $10.41 \%$ of the population will experience slight damage, $4.66 \%$ will experience moderate damage, $0.63 \%$ will experience extensive, and $0.03 \%$ will be completely destructed. Based on the results, buildings that are built to higher standard code regulations can drastically reduce associated repair and damage costs. The additional energy needed for repair would contribute to an individual steel building's life-cycle impact, and should be deliberated in the design phase of a project. The estimated energy consumption for each building design code is an underestimate of the total impact that it would have, due to the fact that each LCA completed only included each building's structural frame. 
Table 7: Steel Building Damage Cost from Northridge Earthquake

\begin{tabular}{|c|c|c|c|c|c|c|}
\hline $\begin{array}{l}\text { Design } \\
\text { Code }\end{array}$ & $\begin{array}{l}\text { Damage } \\
\text { State }\end{array}$ & $\begin{array}{c}\text { Probability } \\
\text { of Damage } \\
\% \\
\end{array}$ & $\begin{array}{l}\text { Replacement } \\
\text { Cost \% }\end{array}$ & $\begin{array}{l}\text { Damage } \\
\text { Ratio \% }\end{array}$ & $\begin{array}{c}\text { Damage } \\
\text { Cost } \\
\$ \\
\end{array}$ & $\begin{array}{c}\text { Repair } \\
\text { Energy } \\
\text { MJ }\end{array}$ \\
\hline \multirow{5}{*}{ High } & Slight & 10.41 & 0.4 & 0.0004164 & \multirow{5}{*}{38,226} & \multirow{5}{*}{33,565} \\
\hline & Moderate & 4.66 & 1.9 & 0.0008854 & & \\
\hline & Extensive & 0.63 & 9.6 & 0.0006048 & & \\
\hline & Complete & 0.03 & 19.2 & 0.0000576 & & \\
\hline & & & Total & 0.0019642 & & \\
\hline \multirow{5}{*}{ Moderate } & Slight & 9.09 & 0.4 & 0.0003636 & \multirow{5}{*}{76,385} & \multirow{5}{*}{67,069} \\
\hline & Moderate & 6.87 & 1.9 & 0.0013053 & & \\
\hline & Extensive & 1.85 & 9.6 & 0.001776 & & \\
\hline & Complete & 0.25 & 19.2 & 0.00048 & & \\
\hline & & & Total & 0.0039249 & & \\
\hline \multirow{5}{*}{ Pre-Code } & Slight & 11.16 & 0.4 & 0.0004464 & \multirow{5}{*}{266,048} & \multirow{5}{*}{233,602} \\
\hline & Moderate & 12.96 & 1.9 & 0.0024624 & & \\
\hline & Extensive & 6.21 & 9.6 & 0.0059616 & & \\
\hline & Complete & 2.5 & 19.2 & 0.0048 & & \\
\hline & & & Total & 0.0136704 & & \\
\hline
\end{tabular}

Table 8 estimates that $23.34 \%$ of the regions steel buildings, built to high code standards, will experience slight damage, $11.39 \%$ moderate damage, $1.19 \%$ extensive damage, and $0.03 \%$ of complete destruction under a 100 -year return event. Resulting in a total cost of repair damage of $\$ 83,640$ and requires 73,440 mega joules of energy. As the building design code standard decrease these numbers increase in cost and environmental impact. 
Table 8: Steel Building Damage Cost from 100-Year Return Earthquake

\begin{tabular}{|c|c|c|c|c|c|c|}
\hline $\begin{array}{l}\text { Design } \\
\text { Code }\end{array}$ & $\begin{array}{l}\text { Damage } \\
\text { State }\end{array}$ & $\begin{array}{c}\text { Probability } \\
\text { of Damage } \\
\%\end{array}$ & $\begin{array}{l}\text { Replacement } \\
\text { Cost \% }\end{array}$ & $\begin{array}{l}\text { Damage } \\
\text { Ratio \% }\end{array}$ & $\begin{array}{c}\text { Damage } \\
\text { Cost } \\
\$\end{array}$ & $\begin{array}{c}\text { Repair } \\
\text { Energy } \\
\text { MJ }\end{array}$ \\
\hline \multirow{5}{*}{ High } & Slight & 23.34 & 0.4 & 0.0009336 & \multirow{5}{*}{83,640} & \multirow{5}{*}{73,440} \\
\hline & Moderate & 11.39 & 1.9 & 0.0021641 & & \\
\hline & Extensive & 1.19 & 9.6 & 0.0011424 & & \\
\hline & Complete & 0.03 & 19.2 & 0.0000576 & & \\
\hline & & & Total & 0.0042977 & & \\
\hline \multirow{5}{*}{ Moderate } & Slight & 21.21 & 0.4 & 0.0008484 & \multirow{5}{*}{169,110} & \multirow{5}{*}{148,486} \\
\hline & Moderate & 18.38 & 1.9 & 0.0034922 & & \\
\hline & Extensive & 3.97 & 9.6 & 0.0038112 & & \\
\hline & Complete & 0.28 & 19.2 & 0.0005376 & & \\
\hline & & & Total & 0.0086894 & & \\
\hline \multirow{5}{*}{ Pre-Code } & Slight & 16.01 & 0.4 & 0.0006404 & \multirow{5}{*}{735,719} & \multirow{5}{*}{645,995} \\
\hline & Moderate & 33.76 & 1.9 & 0.0064144 & & \\
\hline & Extensive & 20.45 & 9.6 & 0.019632 & & \\
\hline & Complete & 5.79 & 19.2 & 0.0111168 & & \\
\hline & & & Total & 0.0378036 & & \\
\hline
\end{tabular}

Table 9 provides the average annual damage probabilities that could possibly occur to the general steel building population. In one year a typical steel building will experience $\$ 4,673$ of damage repair costs and will consume 4,103 MJ of energy.

Table 9: Steel Building Annualized Seismic Damage Cost

\begin{tabular}{|c|c|c|c|c|c|c|}
\hline $\begin{array}{l}\text { Design } \\
\text { Code }\end{array}$ & $\begin{array}{l}\text { Damage } \\
\text { State }\end{array}$ & $\begin{array}{c}\text { Probability } \\
\text { of Damage } \\
\%\end{array}$ & $\begin{array}{l}\text { Replacement } \\
\text { Cost } \%\end{array}$ & $\begin{array}{l}\text { Damage } \\
\text { Ratio \% }\end{array}$ & $\begin{array}{c}\text { Damage } \\
\text { Cost } \\
\$\end{array}$ & $\begin{array}{c}\text { Repair } \\
\text { Energy } \\
\text { MJ }\end{array}$ \\
\hline \multirow{5}{*}{ High } & Slight & 1.53 & 0.4 & 0.0000612 & \multirow{5}{*}{1,894} & \multirow{5}{*}{1,663} \\
\hline & Moderate & 0.19 & 1.9 & 0.0000361 & & \\
\hline & Extensive & $\mathbf{0}$ & 9.6 & 0 & & \\
\hline & Complete & $\mathbf{0}$ & 19.2 & 0 & & \\
\hline & & & Total & 0.0000973 & & \\
\hline \multirow{5}{*}{ Moderate } & Slight & 1.15 & 0.4 & 0.000046 & \multirow{5}{*}{4,673} & \multirow{5}{*}{4,103} \\
\hline & Moderate & 0.87 & 1.9 & 0.0001653 & & \\
\hline & Extensive & 0.03 & 9.6 & 0.0000288 & & \\
\hline & Complete & $\mathbf{0}$ & 19.2 & 0 & & \\
\hline & & & Total & 0.0002401 & & \\
\hline
\end{tabular}




\subsubsection{Concrete Building HAZUS-MH Results}

Table 10 provides the data that was used in the damage analysis for the concrete building.

Table 10: HAZUS-MH Concrete Data for Damage Cost Calculations

\begin{tabular}{|l|c|}
\hline Concrete - Energy per Replacement Cost of Building (MJ / \$) & $\mathbf{1 . 6 2}$ \\
\hline Concrete Building Total Cost Replacement Value (\$ / SF) & $\mathbf{1 8 3 . 8 7}$ \\
\hline Energy for Building, 60-year lifespan (MJ / SF) & $\mathbf{2 9 7}$ \\
\hline
\end{tabular}

The energy per replacement cost for the concrete building is approximately $50 \%$ more than that of the steel building. This is due to the steel buildings greater cost and lesser calculated environmental impact, however this study has made several assumptions and these results are very specific to this case.

Table 11 describes the damage that would occur, to the general concrete building population, if a Northridge event hit the Los Angeles, CA area.

Table 11: Concrete Building Damage Cost from Northridge Earthquake

\begin{tabular}{|c|c|c|c|c|c|c|}
\hline $\begin{array}{l}\text { Design } \\
\text { Code }\end{array}$ & $\begin{array}{l}\text { Damage } \\
\text { State }\end{array}$ & $\begin{array}{c}\text { Probability } \\
\text { of Damage } \\
\%\end{array}$ & $\begin{array}{l}\text { Replacement } \\
\text { Cost } \%\end{array}$ & $\begin{array}{l}\text { Damage } \\
\text { Ratio \% }\end{array}$ & $\begin{array}{c}\text { Damage } \\
\text { Cost } \\
\$\end{array}$ & $\begin{array}{c}\text { Repair } \\
\text { Energy } \\
\text { MJ }\end{array}$ \\
\hline \multirow{5}{*}{ High } & Slight & 9.65 & 0.4 & 0.000386 & \multirow{5}{*}{22,276} & \multirow{5}{*}{35,982} \\
\hline & Moderate & 2.62 & 1.9 & 0.0004978 & & \\
\hline & Extensive & 0.42 & 9.6 & 0.0004032 & & \\
\hline & Complete & 0.06 & 19.2 & 0.0001152 & & \\
\hline & & & Total & 0.0014022 & & \\
\hline \multirow{5}{*}{ Moderate } & Slight & 9.23 & 0.4 & 0.0003692 & \multirow{5}{*}{48,436} & \multirow{5}{*}{78,237} \\
\hline & Moderate & 5.11 & 1.9 & 0.0009709 & & \\
\hline & Extensive & 1.48 & 9.6 & 0.0014208 & & \\
\hline & Complete & 0.15 & 19.2 & 0.000288 & & \\
\hline & & & Total & 0.0030489 & & \\
\hline \multirow{5}{*}{ Pre-Code } & Slight & 12.56 & 0.4 & 0.0005024 & \multirow{5}{*}{167,727} & \multirow{5}{*}{270,924} \\
\hline & Moderate & 11.29 & 1.9 & 0.0021451 & & \\
\hline & Extensive & 5.12 & 9.6 & 0.0049152 & & \\
\hline & Complete & 1.56 & 19.2 & 0.0029952 & & \\
\hline & & & Total & 0.0105579 & & \\
\hline
\end{tabular}

Table 12, below, provides the damage data that would occur to the general concrete building population within Los, Angele CA if a 100-year return event took place. 
Table 12: Concrete Building Damage Cost from 100-Year Return Earthquake

\begin{tabular}{|c|c|c|c|c|c|c|}
\hline $\begin{array}{l}\text { Design } \\
\text { Code }\end{array}$ & $\begin{array}{l}\text { Damage } \\
\text { State }\end{array}$ & $\begin{array}{c}\text { Probability } \\
\text { of Damage } \\
\%\end{array}$ & $\begin{array}{l}\text { Replacement } \\
\text { Cost } \%\end{array}$ & $\begin{array}{l}\text { Damage } \\
\text { Ratio \% }\end{array}$ & $\begin{array}{c}\text { Damage } \\
\text { Cost } \\
\$\end{array}$ & $\begin{array}{c}\text { Repair } \\
\text { Energy } \\
\text { MJ }\end{array}$ \\
\hline \multirow{5}{*}{ High } & Slight & 24.23 & 0.4 & 0.0009692 & \multirow{5}{*}{56,819} & \multirow{5}{*}{91,778} \\
\hline & Moderate & 6.7 & 1.9 & 0.001273 & & \\
\hline & Extensive & 1.15 & 9.6 & 0.001104 & & \\
\hline & Complete & 0.12 & 19.2 & 0.0002304 & & \\
\hline & & & Total & 0.0035766 & & \\
\hline \multirow{5}{*}{ Moderate } & Slight & 22.06 & 0.4 & 0.0008824 & \multirow{5}{*}{104,138} & \multirow{5}{*}{168,212} \\
\hline & Moderate & 12.88 & 1.9 & 0.0024472 & & \\
\hline & Extensive & 3 & 9.6 & 0.00288 & & \\
\hline & Complete & 0.18 & 19.2 & 0.0003456 & & \\
\hline & & & Total & 0.0065552 & & \\
\hline \multirow{5}{*}{ Pre-Code } & Slight & 20.15 & 0.4 & 0.000806 & \multirow{5}{*}{487,038} & \multirow{5}{*}{786,699} \\
\hline & Moderate & 31.96 & 1.9 & 0.0060724 & & \\
\hline & Extensive & 18.15 & 9.6 & 0.017424 & & \\
\hline & Complete & 3.31 & 19.2 & 0.0063552 & & \\
\hline & & & Total & 0.0306576 & & \\
\hline
\end{tabular}

The annualized seismic damage that a concrete building could possibly experience in any given year is shown in Table 13.

Table 13: Concrete Building Annualized Seismic Damage Cost

\begin{tabular}{|c|c|c|c|c|c|c|}
\hline $\begin{array}{l}\text { Design } \\
\text { Code }\end{array}$ & $\begin{array}{l}\text { Damage } \\
\text { State }\end{array}$ & $\begin{array}{c}\text { Probability } \\
\text { of Damage } \\
\%\end{array}$ & $\begin{array}{c}\text { Replacement } \\
\text { Cost } \%\end{array}$ & $\begin{array}{l}\text { Damage } \\
\text { Ratio \% }\end{array}$ & $\begin{array}{c}\text { Damage } \\
\text { Cost } \\
\$\end{array}$ & $\begin{array}{c}\text { Repair } \\
\text { Energy } \\
\text { MJ }\end{array}$ \\
\hline \multirow{5}{*}{ High } & Slight & 0.59 & 0.4 & 0.0000236 & \multirow{5}{*}{375} & \multirow{5}{*}{606} \\
\hline & Moderate & $\mathbf{0}$ & 1.9 & 0 & & \\
\hline & Extensive & $\mathbf{0}$ & 9.6 & 0 & & \\
\hline & Complete & $\mathbf{0}$ & 19.2 & 0 & & \\
\hline & & & Total & 0.0000236 & & \\
\hline \multirow{5}{*}{ Moderate } & Slight & 0.54 & 0.4 & 0.0000216 & \multirow{5}{*}{1,218} & \multirow{5}{*}{1,968} \\
\hline & Moderate & 0.29 & 1.9 & 0.0000551 & & \\
\hline & Extensive & $\mathbf{0}$ & 9.6 & 0 & & \\
\hline & Complete & 0 & 19.2 & 0 & & \\
\hline & & & Total & 0.0000767 & & \\
\hline
\end{tabular}

As can be seen, the difference from high code to moderate code is very substantial, both in repair costs and environmental impacts. In one year of its life, a typical concrete building, will experience 1,218 of damage and consume 1,968 MJ of energy. 


\subsection{Results Discussion}

Reviewing the results obtained for the concrete and steel building's, annual damage and repair costs and associated environmental impacts, it was determined that the population of concrete buildings did have less annual loss considering both high and moderate code standards. HAZUS-MH methodologies take into consideration each building's location and underlying soil type. The fact that the results depict less concrete building damage does not necessary imply that concrete building's behave better under seismic events. Additionally the seismic design codes for each building type progress at different rates and this could have resulted in the concrete building population to have less estimated damage. The Northridge event was examined to see the differences in each building behavior but the given results are very subjective to HAZUS-MH methodology and all premade assumptions about each building type. The future research and section of this paper will discuss these issues and will suggest better analyses to use to better understand building's environmental impacts when subjected to seismic events.

\section{Building Energy Consumption when Subjected to Seismic Events}

Table 14 illustrates the total environmental impacts comparing steel to concrete. As can be seen the steel building was determined to outperform the concrete building when considering each buildings life-cycle assessment; although when considering HAZUSMH results the annual damage loss data was greater for the steel population then the concrete building population. Cost, seismic resiliency, and environmental impacts all 
need to be considered to create a sustainable design. One needs to consider the investing more initially and weigh the long term benefits of doing so.

Table 14: Overall Life-Cycle Impacts Including Seismic Damage

\begin{tabular}{|c|c|c|c|c|}
\cline { 3 - 4 } \multicolumn{2}{c|}{} & $\begin{array}{c}\text { LCA Energy } \\
\text { MJ / SF }\end{array}$ & $\begin{array}{c}\text { Annual Earthquake } \\
\text { Repair Energy } \\
\text { (MJ / 60 years) /SF }\end{array}$ & $\begin{array}{c}\text { Overall } \\
\text { Environmental } \\
\text { Impact } \\
\text { MJ / SF }\end{array}$ \\
\hline $\begin{array}{c}\text { Steel } \\
\text { Building }\end{array}$ & $\begin{array}{c}\text { High Design } \\
\text { Level }\end{array}$ & 8,949 & 1.15 & $8,950.15$ \\
\cline { 2 - 5 } & $\begin{array}{c}\text { Moderate } \\
\text { Design Level }\end{array}$ & 8,949 & 2.85 & $8,951.85$ \\
\hline \multirow{2}{*}{$\begin{array}{c}\text { Concrete } \\
\text { Building }\end{array}$} & $\begin{array}{c}\text { High Design } \\
\text { Level }\end{array}$ & 9,048 & 0.42 & $9,048.42$ \\
\cline { 2 - 5 } & $\begin{array}{c}\text { Moderate } \\
\text { Design Level }\end{array}$ & 9,048 & 1.37 & $9,049.37$ \\
\hline
\end{tabular}

Table 14 represents the total LCA impact of each building including their estimate annual seismic damage for 60 years. The results illustrate that the seismic repair damage environmental effects are a small portion of a building's total overall LCA impact. The steel building repair damage is approximately $.58 \%$ of its total embodied energy and the concrete building's repair damage is approximately $.14 \%$ of its total embodied energy (each having high design level). While this repair energy is a small portion of building total LCA, future research needs to be completed to effectively understand environmental implications of seismic events. Recommendations for future research to examine other avenues on this vein of research will be discussed subsequently.

\section{Future Research Recommendations}

Linking LCA and estimated seismic repair damage effects is difficult due to the fact that both evaluations are not an exact science. This study examined two building frames and 
did not include non-structural building items, future research should examine full building envelope LCA's to pair with estimated seismic damage repair. The structural frame does have the most substantial impact when comparing two structure's seismic resiliency, although the non-structural components of a building would additionally contribute to a building's LCA impact.

Future research should examine the environmental effects of non-structural damage to the operating costs for a building. This paper determined that a building's operational energy is the largest contributor to the building's overall LCA and seismic damage to any system that could potentially effect a building's energy usage could lead to great costs and environmental impacts. HAZUS-MH could additionally be used to estimate nonstructural damage and this data could be used to examine its role in affecting a building's operation energy usages.

The author additionally suggests utilizing HAZUS-MH for individual seismic evaluation. This study used the probability for each building type using the general building population for each, although this is a good average estimation of damage, location and epicenter of earthquakes effects estimated damage results. An individual building examination would eliminate these issues and provide a more accurate damage and repair estimation.

LCAs are independently challenging without considering natural hazard damage effects, other programs such as Athena should incorporate natural hazard damages. More incentives should be awarded to building's that include natural hazard mitigation design strategies. Environmental programs like LEED should include this in their standardizations. 


\section{Conclusions}

Using Athena and HAZUS-MH, this study evaluated the performance of steel and concrete buildings considering their life-cycle assessments and earthquake resistance. It was determined that code design-level greatly effects a building repair and damage estimations. This study presented two case study buildings and found specific results that were obtained using several premade assumptions. Future research recommendations were provided to make this methodology more useful in real-world applications. Examining cost and environmental impacts that a building has through, a cradle to grave analysis and seismic damage assessment, will help reduce material consumption and construction activities from taking place before and after an earthquake event happens. 


\section{References:}

Athena ${ }^{\circledR}$ Eco-Calculator for Buildings V3.71 Software and Database Overview. (2013). Athena Sustainable Materials Institute, Ontario, Canada.

Athena ${ }^{\circledR}$ Impact Estimator for Buildings V3.71 Software and Database Overview. (2013). Athena Sustainable Materials Institute, Ontario, Canada.

Cole, R.J. and Kernan P.C. (1996). "Life-cycle energy use in office buildings." Building and Environment. 31, 307-317.

Comber, M., Poland, S.E., Sinclair, M. (2012). "Environmental Impact Seismic Assessment: Application of Performance-Based Earthquake Engineering Methodologies to Optimize Environmental Performance.” Structures Congress 2012: 910-921.

D.O.E., U.S. (1983). Annual energy review. Washington, D.C., Energy Information Administration, Office of Energy Markets and End Use.

D.O.E., U.S. (1993). Assumptions for the Annual energy outlook. Washington, D.C., Energy Information Administration, Office of Energy Markets and End Use.

D.O.E., U.S. (2013). “Buildings Energy Data Book,” Chapter 1: Building Sector. Washington, D.C.

DeLong, D., Rodriguez,J, McDonnell, T., Stek, E. (2011). "Life-cycle Assessment Using Athena Impact Estimator for Buildings: A Case Study," Structures Congress 2011: 483-494.

Federal Emergency Management Agency (FEMA). (2002) "HAZUS market characterization study: HAZUS is your natural hazard loss estimation methodology: earthquake, wind, and flood." FEMA. Washington, D.C.

Federal Emergency Management Agency (FEMA). (2008) "HAZUS-MH estimated annualized earthquake losses for the United States," FEMA 366. Washington, D.C.

Federal Emergency Management Agency (FEMA). (2013) "Multi-hazard Loss Estimation Methodology." Earthquake Model HAZUS-MH 2.1 Technical Manual. Washington, D.C.

Folger, P. (2011). “Earthquakes: Risk, Detection, Warning, and Research.” Congress Research Service 7-5700. 
Guggemos, Angela Acree and Horvath, Arpad. (2005). "Comparison of Environmental Effects of Steel- and Concrete-Framed Buildings." Journal of Infrastructure Systems, Vol 11, No. 2, 93-101, ASCE.

Horvath, A. (2004). "Construction materials and the Environment," Annual Review of Environment and Resources 29: 181-204.

International Standard 14040 (1997) Environmental management - life cycle assessment - principles and framework, $1^{\text {st }}$ ed., 15 June 1997, Geneva: International Organization for Standardization (ISO).

Johnson, T.W. (2006). "Comparison of environmental impacts of steel and concrete as building materials using the life-cycle assessment method," Massachusetts Institute of Technology. Cambridge, MA.

Kircher, C., Whitman, R., Holmes, W. (2006). "HAZUS Earthquake Loss Estimation Methods." Natural Hazards Review 7(2): 45-59.

Kneer and Maclise (2008). "Consideration of Building Performance in Sustainable Design: A Structural Engineer's Role.” Structural Engineers Association California: 1-15.

LEED. U.S. Green Building Council. Web. 31 Oct. 2012. <https://new.usgbc.org/leed> .

Menna, C., Asprone D., Jalayer, F., Prota, A., Manfredi, G. (2013). "Assessment of ecological sustainability of a building subjected to potential seismic events during its lifetime." The International Journal of Life Cycle Assessment 18(2): 504-515.

Padgett, J.E. and Tapia, C. (2012). "Examining the integration of sustainability and natural hazard risk mitigation into life-cycle analyses of structures." Structural Congress: 1929-1940.

Ploeger, S.K., Atkinson, G.M., Samson, C. (2010). "Applying the HAZUS-MH software tool to assess seismic risk in downtown Ottawa, Canada." Natural Hazards 53(1): $1-20$.

Reed Construction Data Inc. Cost Estimate for Buildings V5.0.1 (2013) Retrieved 04-072013 from <http://buildingsdatabook.eren.doe.gov/ChapterIntro1.aspx $\geq$.

Taghavi S, Miranda E (2003) Response assessment of non-structural elements. PEER Report 2003/05, Pacific Earthquake Engineering Research Center, Berkley.

USGS (2013). "Historic Earthquake: Northridge, California” USGS 
World Commission on Environment and Development. (1987). Our common future. Oxford; New York, Oxford University Press. 